Gut, 1981, 22, 1025-1030

\title{
Increased suppressor cell activity in inflammatory bowel disease
}

\author{
G HOLDSTOCK, BETTE F CHASTENAY, AND E L KRAWITT*
}

From the Department of Medicine, University of Vermont, Burlington, USA

SUMMARY We studied the in vitro effect of indomethacin, hydrocortisone, sulphasalazine, and its metabolites sulphapyridine(SP) and 5-amino salicylic acid (5-ASA) on peripheral blood mononuclear cells (PBMC) from 49 patients with inflammatory bowel disease and 34 controls. Indomethacin caused a highly significant increase in the PBMC response to the mitogen PHA-P compared with controls $(P<0.01)$, indicating increased activity of a prostaglandin-producing suppressor cell system. On the contrary, sulphasalazine resulted in a reduced response which was significantly greater for the group with inflammatory bowel disease than the control group $(P<0.05)$. This reduction was also produced by 5 -ASA $(P<0.05)$ but not by sulphapyridine. Addition of indomethacin to PBMC incubated with sulphasalazine significantly reduced the effect of sulphasalazine $(P<0.001)$. Hydrocortisone resulted in a reduced response which was similar to that of controls and was not altered by the addition of indomethacin. The response to indomethacin, hydrocortisone, sulphasalazine, sulphapyridine, and 5-ASA was not dependent on the HLA type of the patients, disease activity, or drug therapy. The results suggest that increased suppression by a population of prostaglandinproducing suppressor cells plays a role in the immunopathology of inflammatory bowel disease, but that sulphasalazine does not exert its therapeutic effect by acting on this step of the immunoregulatory system. Any trials of indomethacin therapy in inflammatory bowel disease should take into account that, in vitro, sulphasalazine and indomethacin have opposing mechanisms of action in this system.

The discovery of increased levels of prostaglandinlike material in rectal biopsy material ${ }^{1-4}$ and in the faecal content ${ }^{5}$ of patients with inflammatory bowel disease has led to suggestions for a possible role for prostaglandins in the pathogenesis of the disease ${ }^{6}$. Reports of the beneficial effect of indomethacin in conditions such as post-radiation colitis? , food allergies $^{8}$, and irritable bowel disease ${ }^{9}$ have stimulated further interest in the effects of prostaglandin synthetase inhibitors in inflammatory bowel disease. Similarly, although the mode of action of sulphasalazine is unknown, it has been postulated that sulphasalazine itself may act as a prostaglandin synthetase inhibitor ${ }^{6}$.

After the description of prostaglandin producing suppressor cells, sensitive to indomethacin ${ }^{10}$, in a variety of conditions including sarcoidosis ${ }^{11}$ and Hodgkin's disease ${ }^{12}$, we have used this system to study the in vitro effect of indomethacin, hydrocortisone, and sulphasalazine and its metabolites

Address for reprint requests: Dr Edward L Krawitt, Department of Medicine, University of Vermont, Burlington, VT 05405, USA.

Received for publication 7 May 1981 sulphapyridine and 5-amino salicylic acid (5-ASA) on peripheral blood mononuclear cells (PBMC) from patients with inflammatory bowel disease. We hoped to be able to compare and contrast the actions of the drugs to gain insight into the mode of action of sulphasalazine, particularly to investigate the possibility that it may act as a prostaglandin synthetase inhibitor.

\section{Methods}

\section{PATIENTS}

Forty-nine patients with inflammatory bowel disease and 34 controls were studied. All patients were classified on evidence gained from radiographic studies, sigmoidoscopy, and biopsy material. Patients were classified on clinical grounds as being in an active stage of the disease or in remission. A record of the patient's medication was taken with particular reference to sulphasalazine and corticosteroid use. The study conformed to the guidelines of, and was approved by, the Committee on Human Experimentation at the University of Vermont. 
PREPARATION AND CULTURE OF PBMC Peripheral venous blood was drawn into syringes containing preservative-free heparin $(10 \mathrm{U} / \mathrm{ml})$. Mononuclear cells were isolated by centrifugation over Ficoll/Hypaque and were washed twice in phosphate buffered saline. All suspensions were made in RPMI 1640 with $25 \mathrm{mM}$ hepes (Gibco Laboratories), supplemented with penicillin (100 $\mathrm{U} / \mathrm{ml})$, streptomycin $(100 \mu \mathrm{g} / \mathrm{ml})$, and $2 \mathrm{mM}$ glutamine. Fifty microlitres containing $1 \times 10^{5}$ PBMC was added to individual wells of flat bottom microtitre plates (Costar, Cambridge, MA. $6.4 \mathrm{~mm}$ well diameter). Tests were performed on triplicate cultures in a final volume of $0.25 \mathrm{ml}$ containing $10 \%$ heat-inactivated AB serum with mitogens and drugs as indicated below. After incubation at $37^{\circ} \mathrm{C}$ in $5 \%$ $\mathrm{CO}_{2}$ in a fully humid atmosphere for 72 hours, 1 microcurie per well ${ }^{3} \mathrm{H}$ thymidine (New England Nuclear Sp. Act $6.7 \mathrm{C} / \mathrm{mmol}$ aqueous solution) was added. After an additional 18 hours incubation, cells were harvested on glass fibre filters using a Skatron apparatus. The dried filters were counted in minivials by liquid scintillation spectrometry in a Packard Tri-Carb.

\section{MITOGENS AND DRUGS}

Preliminary data showed that the optimum concentration of purified phytohaemagglutinin-P (PHAP) was $1 \mu \mathrm{g} /$ well, concanavalin-A (Con-A) $5 \mu \mathrm{g} /$ well, and pokeweed (PWM) $10 \mu \mathrm{g} /$ well and these concentrations were used throughout. Similarly, optimum concentrations for indomethacin appeared to be $250 \mu \mathrm{g} /$ well, as reported by Goodwin in his original description of the assay ${ }^{10}$. The concentration of hydrocortisone used was $250 \mu \mathrm{g} / \mathrm{well}$. Incubation of PBMC with increasing doses of sulphasalazine and its metabolites showed that the response to PHA-P fell off rapidly with increasing drug levels, indicating toxicity. For these experiments, concentrations similar to pharmacologically achieved blood levels were chosen which resulted in minimal reduction of the response to PHA-P in controls and were $25 \mu \mathrm{g} /$ well for sulphasalazine and its two metabolites sulphapyridine and 5-ASA.

\section{PRESENTATION AND ANALYSIS OF DATA}

Results of the response to the mitogens are expressed as counts per minute, plus or minus one standard deviation. Each reading was a mean of triplicate experiments. The reading in each triplicate was generally within $10 \%$ of the mean. The effects of the drugs on the response to PHA-P was recorded as a percentage of the original response to PHA-P in the absence of the drug. One-way analysis of variance and Student's $t$ test were used for statistical analysis.

\section{Results}

Thirty-four patients with Crohn's disease, 15 patients with ulcerative colitis, and 34 controls were studied. Twenty-five of the patients had active disease and 24 were in remission. Eleven were taking sulphasalazine alone, 19 prednisone alone, and 18 were on no treatment. The remaining patient was taking both drugs. The results of the response to PHA-P, Con-A, PWM, and the effects of indomethacin, sulphasalazine, sulphapyridine, and 5ASA are shown in Table 1 and Fig. 1. There was a significant reduction in the response of $\mathrm{PBMC}$ to PHA-P in Crohn's disease compared with controls $(P<0.05)$ but otherwise there was no difference between controls, and patients with Crohn's disease or ulcerative colitis in the response to the other mitogens.

As illustrated in Table 1 and Fig. 2, there was a highly significant increase in the response to indomethacin, indicating increased prostaglandinproducing cell activity in the Crohn's disease group $(13 \cdot 47 \% \pm 23 \cdot 1)$ and ulcerative colitis group $(7 \cdot 8 \% \pm$

Table 1 Result of mitogen and drug responses in inflammatory bowel disease and control subjects

\begin{tabular}{|c|c|c|c|c|c|c|c|c|c|}
\hline Group & $\begin{array}{l}\text { Total } \\
\text { number } \\
\text { studied }\end{array}$ & $\begin{array}{l}P H A \text { Response } \\
C P M \\
M e a n \pm S D\end{array}$ & $\begin{array}{l}\text { ConA Response } \\
C P M \\
\text { Mean } \pm S D\end{array}$ & $\begin{array}{l}P W M \text { Response } \\
C P M \\
\text { Mean } \pm S D\end{array}$ & $\begin{array}{l}\text { IND } \\
\% \text { Control }\end{array}$ & $\begin{array}{l}H C \\
\% \text { Control }\end{array}$ & l $\%$ Control & ${ }_{1}^{S P}$ Control & $\begin{array}{l}5 A S A \\
\% \text { Control }\end{array}$ \\
\hline $\begin{array}{l}\text { Total } \\
\text { controls }\end{array}$ & 34 & $\begin{array}{r}96377 \\
+87864\end{array}$ & $\begin{array}{r}34862 \\
\pm 19578\end{array}$ & $\begin{array}{r}16769 \\
+16454\end{array}$ & $\begin{array}{r}2 \cdot 12 \\
+16 \cdot 8\end{array}$ & $\begin{array}{c}-19 \cdot 8 \\
\pm 23 \cdot 2 \\
(n=16)\end{array}$ & $\begin{array}{l}-13 \cdot 3 \\
\pm 11 \cdot 52 \\
(n=15)\end{array}$ & $\begin{array}{c}-6.9 \\
\pm 10.8 \\
(\mathrm{n}=16)\end{array}$ & $\begin{array}{c}5.3 \\
\pm 18.6 \\
(n=15)\end{array}$ \\
\hline $\begin{array}{l}\text { Crohn's } \\
\text { disease }\end{array}$ & 34 & $\begin{array}{l}71488^{*} \\
\pm 38797\end{array}$ & $\begin{array}{r}34819 \\
+23063\end{array}$ & $\begin{array}{r}19680 \\
\pm 14945\end{array}$ & $\begin{aligned} & 13 \cdot 47 \ddagger \\
& \pm 23 \cdot 1\end{aligned}$ & $\begin{array}{c}-19 \cdot 6 \\
\pm 28 \cdot 3 \\
(n=31)\end{array}$ & $\begin{array}{l}-20 \cdot 4^{*} \\
\pm 24 \cdot 4 \\
(n=30)\end{array}$ & $\begin{array}{c}-10 \cdot 3 \\
\pm 16 \cdot 2 \\
(n=30)\end{array}$ & $\begin{array}{l}-19 \cdot 4^{*} \\
\pm 22 \cdot 3 \\
(n=32)\end{array}$ \\
\hline $\begin{array}{l}\text { Ulcerative } \\
\text { colitis }\end{array}$ & 15 & $\begin{array}{r}76224 \\
\pm 40732\end{array}$ & $\begin{array}{r}30873 \\
+21392\end{array}$ & $\begin{array}{r}20134 \\
\pm 10268\end{array}$ & $\begin{array}{r}7 \cdot 8^{+} \\
\pm 12 \cdot 4^{-}\end{array}$ & $\begin{array}{l}-28 \cdot 3 \\
\pm 14 \cdot 1 \\
(n=11)\end{array}$ & $\begin{array}{l}-24 \cdot 2^{*} \\
\pm 25 \cdot 1\end{array}$ & $\begin{array}{l}-8 \cdot 6 \\
\pm 15.9\end{array}$ & $\begin{array}{l}-30 \cdot 3^{*} \\
\pm 20 \cdot 2\end{array}$ \\
\hline
\end{tabular}

IND: indomethacin. HC: hydrocortisone. SS : sulphasalazine. SP: sulphapyridine. 5 ASA : 5-amino-salicylic acid.

Compared with the control group: ${ }^{*} P 0.05$. $\dagger_{P} 0.02 .+P 0.01$. 


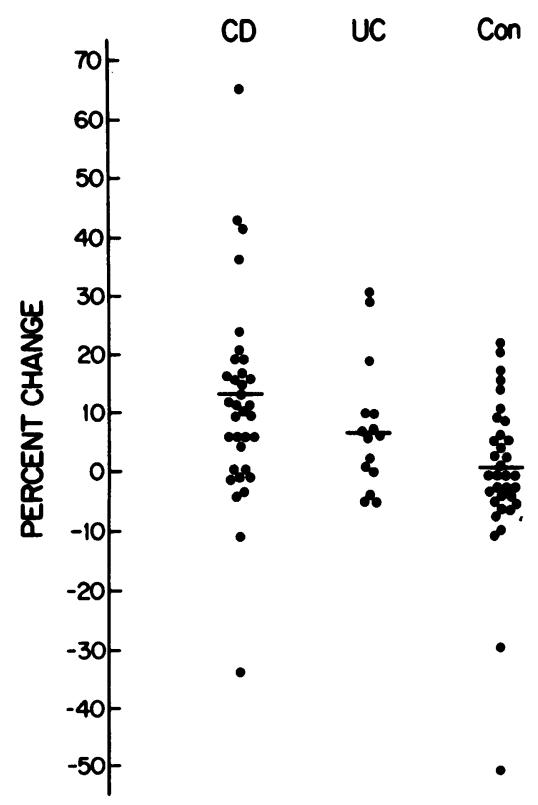

Fig. 1 Effect of indomethacin on lymphocyte response to $P H A-P$ (the prostaglandin-producing suppressor cell activity) CD: Crohn's disease. UC: ulcerative colitis. CON: control).
12.4) compared with the controls $(2 \cdot 1 \% \pm 16 \cdot 8$, $P<0.01$ and $<0.02$ respectively). There was no significant difference between the patients and controls in their response to hydrocortisone. Sulphasalazine caused a significantly greater decrease in ${ }^{3} \mathrm{H}$ thymidine uptake in Crohn's disease $(-20.4 \% \pm 24 \cdot 4)$ and ulcerative colitis $(-24 \cdot 2 \% \pm$ $25 \cdot 1)$ compared with controls $(-13 \cdot 3 \% \pm 11 \cdot 52$, $P<0.05$ ). This relationship was also present for 5 ASA $(P<0.05)$ but not for sulphapyridine. In another group of disease controls (chronic active hepatitis, four; coeliac disease, seven; scleroderma, three), the effects of sulphasalazine, sulphapyridine and 5-ASA were $-11 \cdot 7 \% \pm 11 \cdot 4,-11 \cdot 6 \% \pm 8 \cdot 5$, and $-11.9 \% \pm 16 \cdot 1$ respectively and these results were similar to those obtained in the normal controls and significantly less than those in inflammatory bowel disease for both sulphasalazine and 5-ASA $(\mathrm{P}<0.05)$.

Table 2 shows the results obtained in patients grouped according to disease activity and drug therapy. There was no significant difference between these groups. The response to hydrocortisone, sulphasalazine, sulphapyridine, and 5-ASA from patients with a positive in vitro response to indomethacin was similar to that from patients with a

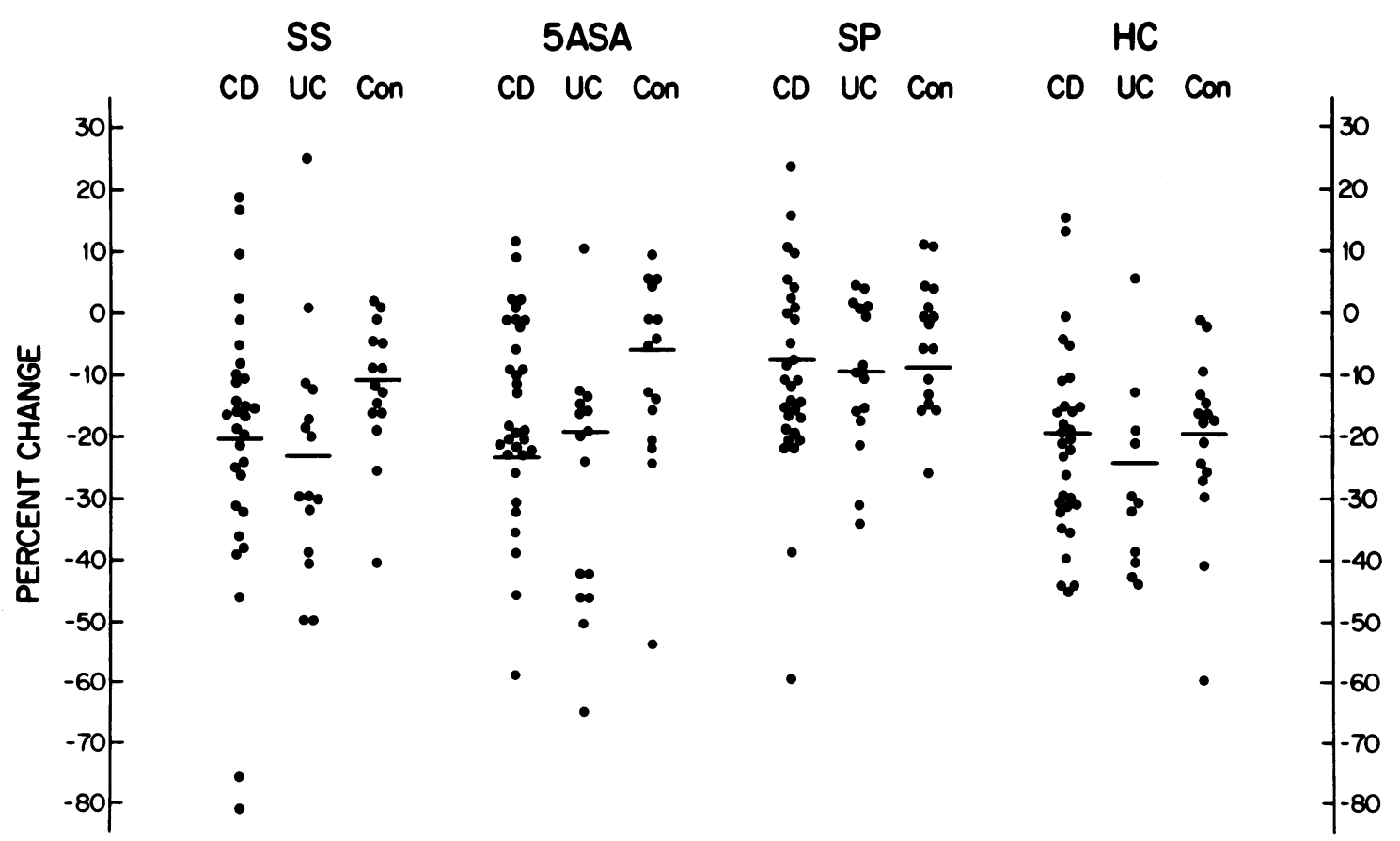

Fig. 2 Effect of sulphasalazine (SS), sulphapyrdine (SP), 5 amino-salicylic acid (5-ASA), and hydrocortisone (HC) on lymphocyte response to PHA-P. (CD:Crohn's disease. UC:ulcerative colitis. CON:controls). 
negative response (Table 3). Thirty of the patients had been HLA A and B typed, and we were able to evaluate the effects of indomethacin with reference to HLA types in these patients. We looked specifically at those that were $B 12$ positive $(n=7)$ and compared them with those who were $B 8$ positive $(n=6)$ and those who were positive to neither of these antigens $(n=17)$. Results were $12 \cdot 4 \% \pm 6 \cdot 0,12 \cdot 8 \% \pm$ 14.6 and $14.2 \% \pm 29.9$ for the three groups. These values were not significantly different from one another.

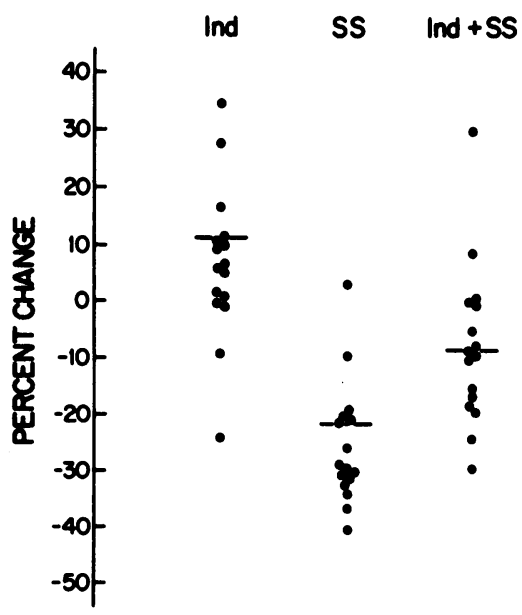

Fig. 3 Effects of sulphasalazine (SS) and indomethacin (IND) separately and together on the lymphocyte response to PHA-P in 16 patients.
Finally, we studied the effect of adding sulphasalazine and indomethacin at the same time on the PHA-P response in 16 patients (Fig. 3). In these patients, indomethacin alone resulted in an increase of $11.4 \% \pm 13.4$ and sulphasalazine alone in a decrease of $21.5 \% \pm 18.4$, values that were comparable with those obtained in the entire patient population. Addition of indomethacin to PBMC incubated with sulphasalazine resulted in a reduction of the PHA-P response to only $8 \cdot 4 \% \pm 14 \cdot 1$. This was significantly less than for sulphasalazinealone $(P<0.001)$, showing that sulphasalazine does not abolish the in vitro effect of indomethacin. Simultaneous incubation of indomethacin with hydrocortisone did not result in the same effect, the results being similar to incubation with hydrocortisone alone $(-17 \cdot 2 \% \pm 16 \cdot 1$ vs$18.4 \% \pm 13 \cdot 9$ ).

\section{Discussion}

We have shown that patients with inflammatory bowel disease have increased indomethacinsensitive, prostaglandin-producing suppressor cells compared with the control group. This is consistent with, and could explain, the known mild reduction in the lymphocyte response to mitogens in patients with inflammatory bowel disease ${ }^{13}{ }^{14}$. Although we did not investigate this in our patients, previous studies have shown that this suppressor cell is probably a prostaglandin-producing monocyte ${ }^{9-11}$, data compatible with the growing number of reports

Table 2 Results of mitogen and effects of IND, SS, and HC in different patient groups

\begin{tabular}{|c|c|c|c|c|c|c|c|}
\hline Group & No. & $\begin{array}{l}\text { PHA response } \\
C P M \\
\text { Mean } \pm S D\end{array}$ & $\begin{array}{l}\text { ConA response } \\
C P M \\
\text { Mean } \pm S D\end{array}$ & $\begin{array}{l}P W M \text { response } \\
C P M \\
\text { Mean } \pm S D\end{array}$ & $\begin{array}{l}\text { IND } \\
\% \text { Control }\end{array}$ & $\begin{array}{l}S S \\
\% \text { Control }\end{array}$ & $\begin{array}{l}H C \\
\% \text { Control }\end{array}$ \\
\hline $\begin{array}{l}\text { Active } \\
\text { disease }\end{array}$ & 25 & $\begin{array}{r}71554 \\
\pm 31520\end{array}$ & $\begin{array}{r}33240 \\
\pm 15442\end{array}$ & $\begin{array}{r}18434 \\
\pm 12040\end{array}$ & $\begin{array}{r}15 \cdot 2 \\
+21 \cdot 8\end{array}$ & $\begin{array}{l}-21 \cdot 1 \\
\pm 25 \cdot 4\end{array}$ & $\begin{array}{l}-19.4 \\
\pm 15.8\end{array}$ \\
\hline In remission & 24 & $\begin{array}{r}80417 \\
\pm 32480\end{array}$ & $\begin{array}{r}36424 \\
\pm 18432\end{array}$ & $\begin{array}{r}18240 \\
\pm 14840\end{array}$ & $\begin{array}{r}10 \cdot 1 \\
\pm 26 \cdot 3\end{array}$ & $\begin{array}{l}-21 \cdot 7 \\
\pm 23 \cdot 4\end{array}$ & $\begin{array}{l}-24.4 \\
\pm 12.4\end{array}$ \\
\hline $\begin{array}{l}\text { Sulphasalazine } \\
\text { only }\end{array}$ & 11 & $\begin{array}{r}78243 \\
\pm 36554\end{array}$ & $\begin{array}{r}31277 \\
\pm 12987\end{array}$ & $\begin{array}{r}12517 \\
\pm 8816\end{array}$ & $\begin{array}{r}9.4 \\
+10.7\end{array}$ & $\begin{array}{l}-16 \cdot 2 \\
\pm 21 \cdot 1\end{array}$ & $\begin{array}{l}-27 \cdot 6 \\
\pm 11 \cdot 2\end{array}$ \\
\hline $\begin{array}{l}\text { Prednisone } \\
\text { only }\end{array}$ & 19 & $\begin{array}{r}77653 \\
\pm 32711\end{array}$ & $\begin{array}{r}30072 \\
\pm 25443\end{array}$ & $\begin{array}{r}27593 \\
\pm 24990\end{array}$ & $\begin{array}{r}19 \cdot 0 \\
+24 \cdot 2\end{array}$ & $\begin{array}{l}-21.6 \\
\pm 24.0\end{array}$ & $\begin{array}{l}-18 \cdot 3 \\
\pm 15 \cdot 3\end{array}$ \\
\hline No treatment & 18 & $\begin{array}{r}77910 \\
\pm 33995\end{array}$ & $\begin{array}{r}42078 \\
+24917\end{array}$ & $\begin{array}{r}18083 \\
\pm 9830\end{array}$ & $\begin{array}{r}12.8 \\
\pm 13.4\end{array}$ & $\begin{array}{l}-26 \cdot 4 \\
\pm 21 \cdot 6\end{array}$ & $\begin{array}{l}-22 \cdot 0 \\
\pm 16 \cdot 4\end{array}$ \\
\hline
\end{tabular}

Table 3 Comparisons of effects of SS, SP, and HC on response to indomethacin

\begin{tabular}{|c|c|c|c|c|c|}
\hline Group & No. & $\begin{array}{l}S S \\
\% \text { Control }\end{array}$ & $\begin{array}{l}S P \\
\% \text { Control }\end{array}$ & $\begin{array}{l}5 A S A \\
\% \text { Control }\end{array}$ & $\begin{array}{l}\text { HC } \\
\% \text { Control }\end{array}$ \\
\hline $\begin{array}{l}\text { Positive response to } \\
\text { indomethacin }\end{array}$ & 39 & $-18 \cdot 3 \pm 16 \cdot 9$ & $-11 \cdot 3 \pm 13 \cdot 5$ & $-22 \cdot 6 \pm 14 \cdot 4$ & $-19 \cdot 0 \pm 17 \cdot 4$ \\
\hline Negative & 10 & $-21 \cdot 8 \pm 16 \cdot 4$ & $-13 \cdot 0 \pm 11 \cdot 8$ & $-27 \cdot 4 \pm 17 \cdot 3$ & $-25 \cdot 3 \pm 10 \cdot 5$ \\
\hline
\end{tabular}


of 'activated macrophages' in inflammatory bowel disease ${ }^{15}$. Whether the increased activity of this suppressor cell system in inflammatory bowel disease is primary and of importance immunopathogenetically, or is an epiphenomenon cannot be determined from this study. The observation that levels were similar in patients with active or quiescent disease suggests that it is primary, although its occurrence in other conditions ${ }^{11} 12$ suggests that it may be a secondary phenomenon. We failed to confirm the suggestion, based on studies in normal controls, that this system is HLAdependent ${ }^{16}$.

Our results suggest that neither sulphasalazine nor corticosteroids exert their therapeutic effect by affecting this limb of the immunoregulatory system. The results might explain the increased levels of prostaglandins that have been found in rectal biopsies in patients with inflammatory bowel disease, as it may be macrophages and not the colonic epithelial cells which produce the prostaglandins. The presence of increased prostaglandin-producing suppressor cell activity suggests a possible role for indomethacin in patients with inflammatory bowel disease and provides additional justification for trials with drugs such as indomethacin, although the observation that concurrent incubation of PBMC with indomethacin and sulphasalazine reduces the effects of sulphasalazine suggests that these two drugs may have antagonistic, although possibly unrelated, modes of action ${ }^{6}$. Indeed, sulphasalazine may act on the monocyte and influence lymphocyte response, possibly by prostaglandin release. Thus, in clinical trials the effect of indomethacin on patients not concurrently taking sulphasalazine should receive special attention. It should also be remembered that, if the increased PgSS is a compensatory response, then blocking it with indomethacin may have a detrimental effect.

Reports have suggested that sulphasalazine may inhibit prostaglandin synthetases ${ }^{5}{ }^{6}$. Our results do not support this, but suggest that it has an immunosuppressant effect which is not dependent on the response to indomethacin. Furthermore, this in vitro effect of indomethacin is not blocked by coincubation with sulphasalazine. Corticosteroids are also thought to have antiprostaglandin properties, possibly by reducing the availability of substrate for prostaglandin synthesis ${ }^{17}$. The in vitro response to hydrocortisone that we observed does not support the suggestion that the main therapeutic role of corticosteroids in inflammatory bowel disease is to reduce prostaglandin synthesis. The coincubation experiments are difficult to interpret but suggest that hydrocortisone, sulphasalazine, and indomethacin all have different modes of activity.
In our view, it is of interest that the reduction of lymphocyte response caused by sulphasalazine is greater in patients with inflammatory bowel disease than in controls, particularly as its effect seemed to be most marked for its metabolite 5-ASA, which appears to be the active metabolite ${ }^{18-20}$ and is not seen with sulphapyridine. However, the difference is small and previous work on the effect of sulphasalazine on lymphocyte responses has failed to show this specificity in inflammatory bowel disease ${ }^{21-}$ 23. Although our finding needs to be confirmed by others, the results are compatible with the hypothesis that sulphasalazine acts on the monocyte which is known to circulate in increased numbers in inflammatory bowel disease.

The response to mitogens of patients receiving sulphasalazine was not reduced compared with those on no treatment. This might argue against an immunosuppressant effect, but nor was there a significant reduction in patients on corticosteroids, which is known to be a potent immunosuppressant. Drug levels of sulphasalazine are particularly high in colonic mucosa and it may be that a local immunosuppressant effect accounts for the beneficial effect of the drug.

In conclusion, the results suggest that there is an increased population of prostaglandin-producing suppressor cells in inflammatory bowel disease, which may play a role in the immunopathogenesis of the disease. There is no evidence in this system that sulphasalazine acts as a prostaglandin synthetase inhibitor. Trials of indomethacin in inflammatory bowel disease will help to determine whether this suppressor cell system is of immunopathogenic importance but should take into account the possibility that indomethacin and sulphasalazine have different and possibly antagonistic modes of action in vivo as well as in vitro. These findings are supported by recent studies on gastrointestinal smooth muscle ${ }^{24}$ which also show that the two drugs have opposite effects.

Supported in part by USPHS grant GCRC RR109 and the Gastrointestinal Vermont Education and Research Fund. Sulphasalazine, sulphapyridine, and 5-amino salicylic acid were kindly supplied by Pharmacia Laboratories and indomethacin by Merck, Sharp and Dohme Research Laboratories. $\mathbf{G} \mathbf{H}$ is in receipt of a Fulbright Travelling Fellowship.

\section{References}

'Harris DW, Smith PR, Swan CHJ. Determination of prostaglandin synthetase activity in rectal biopsy material in colonic disease. Gut 1978; 19: 875-7.

2Sharon P, Ligumsky M, Rachmilewitz D, Zor, U. 
Role of prostaglandins in ulcerative colitis. Enhanced production during active disease and inhibition by sulfasalazine. Gastroenterology 1978; 75:638-40.

${ }^{3}$ Smith PR, Dawson DJ, Swan CHJ. Prostaglandin synthetase activity in acute ulcerative colitis: effects of treatment with sulphasalazine, codeine phosphate and prednisolone. Gut 1979; 20:802-5.

${ }^{4}$ Rampton DS, Sladen GE, Youlten LJF. Rectal mucosal prostaglandin E2 release and its relation to disease activity, electrical potential difference and treatment in ulcerative colitis. Gut 1980; 21 :591-6

${ }^{5}$ Gould SR. Assay of prostaglandin-like substances in faeces and their measurement in ulcerative colitis. Prostaglandins 1976; $11: 489-97$.

${ }^{6}$ Moore PK, Hoult JRS, Laurie AS. Prostaglandins and mechanism of action of sulfasalazine in ulcerative colitis. Lancet 1978; 2 :98-9.

${ }^{7}$ Mennie AT, Dalleq VM, Dineen LC, Collier HO. Treatment of radiation-induced gastrointestinal distress with acetylsalicylate. Lancet 1975 ; 2:942-3.

${ }^{8}$ Buisseret PD, Youlten LJF, Heinzelmann, DI, Lessof MH. Prostaglandin-synthetase inhibitors in prophylaxis of food intolerance. Lancet $1978 ; 1: 906-8$.

${ }^{9}$ Rask-Madsen J, Bukhave K: Indomethacin responsive diarrhoea in irritable bowel syndrome. Gut 1978; 19:A448.

${ }^{10}$ Goodwin JS, Bankhurst AD, Messner RP. Suppression of human $\mathrm{T}$-cell mitogenesis by prostaglandin: existence of a prostaglandin-producing suppressor cell. $J$ Exp Med, 1977; 146:1719-34.

${ }^{11 G o o d w i n ~ J S, ~ D e H o r a t i u s ~ R, ~ I s r a e l ~ H, ~ P e a k e ~ G T, ~}$ Messner RP. Suppressor cell function in sarcoidosis. Ann Intern Med, 1979; 90:169-73.

12Goodwin JS, Messner RP, Bankhurst AD, Peake GT, Saiki JH, Williams RC Jr. Prostaglandin producing suppressor cells in Hodgkins' disease. $N$ Engl J Med 1977; $297: 963-8$.

13Sachar DB, Taub RN, Brown SM, Present DH, Korelitz BI, Janowitz HD. Impaired lymphocyte responsiveness in inflammatory bowel disease. Gastroenterology 1973; 64:203-9.

${ }_{14}$ Whorwell PJ, Wright $\mathrm{R}$. Immunological aspects of inflammatory bowel disease. Clinics Gastroenterology $1976 ; 5: 303-21$.
15Meuret G, Bitzi A, Hammer B. Macrophage turnover in Crohn's disease and ulcerative colitis.Gastroenterology 1978; 74:501-3.

16Staszak C, Goodwin JS, Troup GM, Pathak DR, Williams RC Jr. Decreased sensitivity to prostaglandin and histamine in lymphocytes from normal HLA B12 individuals: A possible role in autoimmunity. $J$ Immunol 1980; 125:181-5.

${ }^{17}$ Floman Y, Zor U. Mechanism of steroid action in inflammation inhibition of prostaglandin synthesis and release. Prostaglandins 1976; 12:403-13.

${ }^{18}$ Azad Khan AK, Piris J, Truelove SC. An experiment to determine the active therapeutic moiety of sulphasalazine. Lancet 1977; 2:892-5.

19 Van Hees PAM, Bakker JH, Can Tongeren JHM. Effect of sulphapyridine, 5-amino-salicylic acid and placebo in patients with idiopathic proctitis: a study to determine the active therapeutic moiety of sulphasalazine. Gut 1980; $21: 632-8$.

${ }^{20}$ Klotz V, Maier K, Fischer, C, Heinkel K. Therapeutic efficacy of sulfasalasalazine and its metabolites in patients with ulcerative colitis and Crohn's disease. $N$ Engl J Med 1980; 303:1499-502.

${ }^{21}$ Das KM, Eastwood MA, McManus JPA, Sircus W. The metabolism of salicylazo- sulphayridine in ulcerative colitis. I. The relationship between metabolites and the response to treatment in patients. II. The relationship between metabolites and the progress of the disease studied in outpatients. Gut $1973 ; 14: 631-41$.

${ }^{22}$ Rubinstein A, Das KM, Melamed J, Murphy RA. Comparative analysis of systemic immunological parameters in ulcerative colitis and idiopathic proctitis: effects of sulfasalazine in vivo and in vitro. Clin Exp Immunol 1978; 33:217-24.

23Thayer WR, Jr., Charland C, Field CE. Effects of sulfasalazine on selected lymphocyte subpopulations in vivo and in vitro. Dig Dis Sci 1979; 24:672-9.

${ }^{24}$ Hoult JRS, Moore PK. Effects of sulphasalazine and its metabolites on prostaglandin synthesis, inactivation, and actions on smooth muscle. Br J Pharmacol 1980; 68:719-30. 